\title{
Quinalizarin induces ROS-mediated apoptosis via the MAPK, STAT3 and NF-кB signaling pathways in human breast cancer cells
}

\author{
YAN-QING ZANG $^{1 *}$, YAN-YU FENG $^{1 *}$, YING-HUA LUO $^{2 *}$, YU-QING ZHAI $^{1}$, XUE-YING JU ${ }^{1}$, \\ YU-CHAO FENG ${ }^{1}$, YA-NAN SHENG ${ }^{1}$, JIA-RU WANG ${ }^{3}$, CHANG-QING YU $^{1}$ and CHENG-HAO JIN ${ }^{1,3}$ \\ ${ }^{1}$ Department of Food Science and Engineering, College of Food Science, ${ }^{2}$ Department of Grass Science, \\ College of Animal Science and Veterinary Medicine, ${ }^{3}$ Department of Biochemistry and Molecular Biology, \\ College of Life Science and Technology, Heilongjiang Bayi Agricultural University, Daqing, Heilongjiang 163319, P.R. China
}

Received December 28, 2018; Accepted July 10, 2019

DOI: $10.3892 / \mathrm{mmr} .2019 .10725$

\begin{abstract}
Quinalizarin has been demonstrated to exhibit potent antitumor activities in lung cancer and gastric cancer cells, but currently, little is known regarding its anticancer mechanisms in human breast cancer cells. The aim of the present study was to investigate the apoptotic effects of quinalizarin in MCF-7 cells and to analyze its molecular mechanisms. The MTT assay was used to evaluate the viability of human breast cancer cells that had been treated with quinalizarin and 5-fluorouracil. Flow cytometric analyses and western blotting were used to investigate the effects of quinalizarin on apoptosis and cycle arrest in MCF-7 cells with focus on reactive oxygen species (ROS) production. The results demonstrated that quinalizarin exhibited significant cytotoxic effects on human breast cancer cells in a dose-dependent manner. Accompanying ROS, quinalizarin induced MCF-7 cell mitochondrial-associated apoptosis by regulating mitochondrial-associated apoptosis, and caused cell cycle arrest at the $\mathrm{G}_{2} / \mathrm{M}$ phase in a time-dependent manner. Furthermore, quinalizarin can activate p38 kinase and JNK, and inhibit the extracellular signal-regulated kinase, signal transducer and activator of transcription 3 (STAT3)
\end{abstract}

Correspondence to: Professor Cheng-Hao Jin, Department of Biochemistry and Molecular Biology, College of Life Science and Technology, Heilongjiang Bayi Agricultural University, 5 Xinfa Street, Daqing, Heilongjiang 163319, P.R. China

E-mail: jinchenghao3727@qq.com

Professor Chang-Qing Yu, Department of Food Science and Engineering, College of Food Science, Heilongjiang Bayi Agricultural University, 5 Xinfa Street, Daqing, Heilongjiang 163319, P.R. China

E-mail: byndycq@163.com

*Contributed equally

Key words: quinalizarin, human breast cancer, cell cycle arrest, apoptosis, reactive oxygen species, mitogen-activated protein kinase, signal transducer and activator of transcription- $3, \mathrm{NF}-\mathrm{\kappa B}$ and NF-кB signaling pathways. These effects were blocked by mitogen-activated protein kinase (MAPK) inhibitor and $\mathrm{N}$-acetyl-L-cysteine. The results from the present study suggested that quinalizarin induced $\mathrm{G}_{2} / \mathrm{M}$ phase cell cycle arrest and apoptosis in MCF-7 cells through ROS-mediated MAPK, STAT3 and NF- $\mathrm{BB}$ signaling pathways. Thus, quinalizarin may be useful for human breast cancer treatment, as well as the treatment of other cancer types.

\section{Introduction}

Breast cancer is the most frequently diagnosed malignancy in women worldwide and the second leading cause of cancer-associated mortality in women after lung cancer; breast cancer is responsible for over one million of the estimated 10 million neoplasms diagnosed worldwide each year in both sexes $(1,2)$. Breast cancer is commonly treated with anti-estrogens, surgical resection, radiotherapy and chemotherapy $(3,4)$. Tamoxifen, aromatase inhibitors, metformin, 5-fluorouracil (5-FU) and cisplatin are widely used in the treatment of breast cancer (5). However, these drugs not only kill cancer cells, but also affect human normal cells. Thus, there is an imperative need to develop more effective and less toxic antitumor drugs.

Inducing cancer cell apoptosis via chemotherapy is a commonly used method in the treatment of various different types of cancer. Apoptosis targets that are currently being investigated for chemotherapy include the mitogen-activated protein kinases (MAPK), signal transducer and activator of transcription-3 (STAT3) and NF- $\kappa$ B signaling pathways $(6,7)$. The MAPK signaling pathways include extracellular-signal-regulated kinase (ERK), c-Jun N-terminal kinase (JNK) and p38, which regulate a variety of cellular behaviors (8). JNK and p38 are activated in response to several stress signals and are associated with the induction of apoptosis. ERK can antagonize apoptosis by phosphorylating pro-apoptotic $\mathrm{Bcl}-2$-associated death promoter (Bax) and anti-apoptotic Bcl-2 proteins, and inhibiting their functions (9). Numerous studies have revealed that STAT3 expression is higher in tumor tissues compared with in normal tissues, and its prolonged activation is associated with a number of different types of malignancy (10). 
$\mathrm{NF}-\kappa \mathrm{B}$, a family of signal-responsive transcription factors, can be maintained in an inactive state within the cytoplasm through interactions and binding to inhibitor of $\kappa \mathrm{B}(\mathrm{i}-\kappa \mathrm{B})$ proteins in normal cells, and has been demonstrated to be activated in cancer cells, including prostate and lung cancer $(11,12)$. These pathways may be triggered in response to extra- or intracellular stimuli, such as reactive oxygen species (ROS) (13).

ROS is an important second messenger in apoptosis and cell signaling (14), and high ROS levels have been suggested to activate intrinsic pathways and induce cell apoptosis (15). A number of studies have used oxidation therapy to treat patients with cancer through increasing ROS generation to induce cancer cell apoptosis (16-19) Therefore, ROS are highly promising drug targets for cancer therapy.

Quinalizarin is an anthraquinone component isolated from Rubiaceae; its anthraquinone ring is similar to the nuclei of antitumor drugs such as doxorubicin and daunorubicin (20). Previous studies have demonstrated that it promotes apoptosis in A549 lung cancer cells, AGS gastric cancer cells, and Huh 7 hepatoma cells via the MAPK and STAT3 signaling pathways $(21,22)$. However, to the best of our knowledge, there are currently no detailed reports describing the effects of quinalizarin in human breast cancer.

In the present study, in order to determine whether quinalizarin induced human breast cancer cell mortality and decreased normal cells toxicity, the cytotoxic effects, apoptotic effects, cell cycle, ROS effects and key molecular signaling proteins involved in regulation of apoptosis were investigated in human breast cancer cells.

\section{Materials and methods}

Chemicals and reagents. In the present study, 5-fluorouracil (5-FU; MedChem Express) was dissolved in $20 \mathrm{mM}$ 100\% dimethyl sulfoxide (DMSO). Quinalizarin (Sigma-Aldrich; Merck KGaA) was prepared as a stock solution in DMSO and stored at $-20^{\circ} \mathrm{C}$ until use.

Cell cultures. Human breast cancer estrogen-dependent cell lines (MCF-7, T47D and MDA-MB231) were purchased from the American Type Culture Collection and normal human cells (L-02, IMR-90 and 293-T) were obtained from Sai Qi (Shanghai) Biological Engineering Co., Ltd. The human normal liver cells (L-02), human lung fibroblast cells (IMR-90) and normal kidney epithelial cells (293-T) were used as controls as the liver and kidneys are major target organs for drug toxicity testing, and IMR-90 cells have not transformed from embryonic cells, which can directly reflect the effects of toxicity in toxicity studies. MCF-7, T47D and MDA-MB231 cells were grown in Dulbecco's modified Eagle's medium (DMEM; Gibco; Thermo Fisher Scientific, Inc.). L-02, IMR-90 and 293-T cells were grown in RPMI-1640 medium (Gibco; Thermo Fisher Scientific, Inc.) supplemented with 10\% FBS (Gibco; Thermo Fisher Scientific, Inc.), $100 \mathrm{U} / \mathrm{ml}$ penicillin (Gibco; Thermo Fisher Scientific, Inc.) and $100 \mu \mathrm{g} / \mathrm{ml}$ streptomycin (Gibco; Thermo Fisher Scientific, Inc.), and incubated at $37^{\circ} \mathrm{C}$ with $5 \% \mathrm{CO}_{2}$ for $24 \mathrm{~h}$.

MTT assay. MCF-7, T47D, MDA-MB231, L-02, IMR-90 and 293-T cells were harvested in the logarithmic growth phase and then seeded in 96-well culture plates at a density of $6 \times 10^{3}$ cells/per well. After $24-\mathrm{h}$ incubation at $37^{\circ} \mathrm{C}$, the cells were treated with different concentrations (1, 3, 10, 30 and $100 \mu \mathrm{mol} / \mathrm{l}$ ) of $5-\mathrm{FU}$ or quinalizarin for $24 \mathrm{~h}$. Cells in the control group were treated with DMSO. The cells were then incubated with $20 \mu \mathrm{l} \mathrm{MTT}(5 \mathrm{mg} / \mathrm{ml})$ for $2 \mathrm{~h}$ at $37^{\circ} \mathrm{C}$. The intracellular formazan crystals were solubilized with $100 \mu \mathrm{l}$ DMSO and incubated for $15 \mathrm{~min}$ at $37^{\circ} \mathrm{C}$, after which the absorbance of the solutions was measured at $490 \mathrm{~nm}$ (BioTek Instruments, Inc.). The half maximal inhibitory concentration $\left(\mathrm{IC}_{50}\right)$ values were calculated using GraphPad Prism version 5.01 (GraphPad Software, Inc.).

Hoechst 33324 staining. Apoptosis was analyzed using Hoechst 33324 (Beyotime Institute of Biotechnology) staining. MCF-7 cells were seeded onto cell slides in 6-well plates $\left(1 \times 10^{5}\right.$ cells/per well $)$ and treated with $10 \mu \mathrm{mol} / 1$ 5-FU or $10 \mu \mathrm{mol} / 1$ quinalizarin for $3,6,12$ and $24 \mathrm{~h}$ at $37^{\circ} \mathrm{C}$. After washing twice with PBS, cells were resuspended in $5 \mu$ l Hoechst 33324 binding buffer, and dual staining was performed with $5 \mu \mathrm{l}$ propidium iodide (PI; Beyotime Institute of Biotechnology) for $5 \mathrm{~min}$ at $37^{\circ} \mathrm{C}$. Cells were incubated with Hoechst 33324 stain for $5 \mathrm{~min}$ at $37^{\circ} \mathrm{C}$ and observed under a fluorescence microscope DM 2500 (Leica Microsystems $\mathrm{GmbH})$ at magnification, $\mathrm{x} 400$.

Annexin V-fluorescein isothiocyanate (FITC)/PI double staining and flow cytometry. Early and late apoptosis were analyzed by flow cytometry. MCF-7 cells were seeded onto cell slides in 6 -well plates $\left(1 \times 10^{5}\right.$ cells/well) and treated with $10 \mu \mathrm{mol} / 15-\mathrm{FU}$ or $10 \mu \mathrm{mol} / 1$ quinalizarin at $3,6,12$ and $24 \mathrm{~h}$, as aforementioned. Cells were centrifuged at 5,000 x $\mathrm{g}$ for 5 min at $4^{\circ} \mathrm{C}$ and washed three times with PBS. A total of $10 \mu 1$ FITC and $5 \mu 1$ PI were incubated with the cell suspension for $20 \mathrm{~min}$ at $37^{\circ} \mathrm{C}$ in the dark and analyzed by flow cytometry (Beckman Coulter, Inc. Brea, CA, USA). CytExpert software 2.0 (Beckman Coulter, Inc.) was used for analysis.

Cell cycle analysis. MCF-7 cells were treated with $10 \mu \mathrm{mol} / 1$ quinalizarinfor 3,6,12 and 24 hat a density of $1 \times 10^{5}$ cells/perwell. Subsequently, the cell culture RPMI-1640 medium (10\% FBS; $100 \mathrm{U} / \mathrm{ml}$ penicillin; $100 \mu \mathrm{g} / \mathrm{ml}$ streptomycin) was removed, and the cells were trypsinized (0.05\% trypsin-EDTA in PBS), washed twice with cold PBS and fixed in $70 \%$ ethanol for $12 \mathrm{~h}$ at $-20^{\circ} \mathrm{C}$. Cell suspensions were then incubated with RNase A and PI (both Beyotime Institute of Biotechnology) for $30 \mathrm{~min}$ at $37^{\circ} \mathrm{C}$ in the dark. The stained cells were analyzed for DNA content using flow cytometry (Beckman Coulter, Inc.). The cell cycle was analyzed using CytExpert software 2.0 (Beckman Coulter, Inc.).

Western blot analysis. MCF-7 cells were pre-incubated for $1 \mathrm{~h}$ with FR180204 (ERK inhibitor, $12 \mu \mathrm{mol} /$ liter) or SP600125 (JNK inhibitor, $12 \mu \mathrm{mol} /$ liter) or SB203580 (p38 inhibitor, $12 \mu \mathrm{mol} /$ liter) (MedChem Express) dissolved in PBS and then treated with $10 \mu \mathrm{mol} / \mathrm{l}$ quinalizarin for $3,6,12$ or $24 \mathrm{~h}$. Proteins were extracted with cell lysis buffer (1 M HEPES, $\mathrm{pH} 7.0 ; 5 \mathrm{M} \mathrm{NaCl} ; 0.5 \%$ Triton X-100; $10 \%$ glycerol; $20 \mathrm{mM}$ $\beta$-mercaptoethanol; $20 \mathrm{mg} / \mathrm{ml}$ AEBSF; $0.5 \mathrm{mg} / \mathrm{ml}$ pepstatin; $0.5 \mathrm{mg} / \mathrm{ml}$ leupeptin; and $2 \mathrm{mg} / \mathrm{ml}$ aprotinin) for $30 \mathrm{~min}$ at $37^{\circ} \mathrm{C}$ 
and centrifuged at $12,000 \mathrm{x}$ g for $30 \mathrm{~min}$ at $4^{\circ} \mathrm{C}$. The protein concentration was quantified using Coomassie blue staining. Equivalent proteins $(30 \mu \mathrm{g})$ were separated via SDS-PAGE (8-12\% gel) and transferred onto nitrocellulose membranes, which were incubated in blocking solution [fresh 5\% non-fat milk in $10 \mathrm{mM}$ Tris- $\mathrm{HCl}$ containing $150 \mathrm{mM} \mathrm{NaCl}$ and Tris-buffered saline (TBS); $\mathrm{pH}$ 7.5] and TBS+0.2\% Tween-20 (TBST) for $1 \mathrm{~h}$ at room temperature. The membranes were incubated for $12 \mathrm{~h}$ at $4^{\circ} \mathrm{C}$ with the following primary antibodies: Mouse monoclonal antibodies against $\alpha$-tubulin (1:2,500; cat. no. sc-8035; internal control), Bax (1:1,500; cat. no. sc-493), Bcl-2 (1:1,500; cat. no. sc-7382), caspase-3 (1:1,500; cat. no. sc-373730), cleaved (cle)-poly (ADP-ribose) polymerase (PARP; 1:1,500; cat. no. sc-8007), phosphorylated (p)-JNK (Tyr ${ }^{183}$ and $\mathrm{Tyr}^{185} ; 1: 1,500$; cat. no. sc-6254), JNK (1:1,500; cat. no. sc-7345), p-p38 (Tyr ${ }^{182} ; 1: 1,500$; cat. no. sc-7973), p-ERK (Tyr ${ }^{204}$; 1:1,500; cat. no. sc-8059), p-STAT3 (Tyr ${ }^{705}$; 1:1,500; cat. no. sc-8059) and STAT3 (1:1,500; cat. no. sc-8019); and rabbit polyclonal antibodies against CDK1/2 (1:2,500; cat. no. sc-163), cyclin B1 (1:2,500; cat. no. sc-4073), p27 (1:2,500; cat. no. sc-528), p21 (1:1,500; cat. no. sc-397), ERK2 (1:1,500; cat. no. sc-154), p38 $\alpha / \beta$ (1:1,500; cat. no. sc-7194), NF-кB (1:2,500; cat. no. sc-1190) and IкB (1:2,500; cat. no. sc-7977; all from Santa Cruz Biotechnology, Inc.). The membranes were incubated with horseradish peroxidase conjugated anti mouse (1:5,000; cat. no. ZB 2301) and anti rabbit (1:5,000; cat. no. ZB 2305; both from OriGene Technologies, Inc.) secondary antibodies for $23 \mathrm{~h}$ at room temperature followed by washing with TBST. Proteins were visualized using Pierce ECL Western Blotting Substrate (Thermo Fisher Scientific, Inc.) and the AI600 chemiluminescence imager (GE Healthcare), and were semi-quantified using ImageJ software (version 1.46r; National Institutes of Health). Protein levels were normalized to the matching densitometry value of $\alpha$-tubulin as the internal control. The change in the expression levels of p-p38, p-JNK, p-ERK and p-STAT3 was based on the expression levels of p38, JNK, ERK and STAT3.

Measurement of intracellular ROS levels. MCF-7 cells were seeded in 6 -well culture plates $\left(1 \times 10^{5}\right.$ cells/per well $)$ and incubated for $24 \mathrm{~h}$, and then treated with $10 \mu \mathrm{mol} / 1$ quinalizarin for 3, 6, 12 and $24 \mathrm{~h}$, as aforementioned. MCF-7 cells were pretreated with $\mathrm{N}$-acetyl-L-cysteine (NAC; Beyotime Institute of Biotechnology) for $30 \mathrm{~min}$ at $37^{\circ} \mathrm{C}$ and then treated with $10 \mu \mathrm{mol} / 1$ quinalizarin for $12 \mathrm{~h}$ at $37^{\circ} \mathrm{C}$. ROS levels were estimated using a fluorescent probe comprising 2',7'-dichlorofluorescin diacetate (DCFH-DA; Beyotime Institute of Biotechnology). The cells were harvested and centrifuged at 5,000 $\mathrm{x}$ g for $5 \mathrm{~min}$ at room temperature and incubated with DCFH-DA for $30 \mathrm{~min}$ at $37^{\circ} \mathrm{C}$ in the dark. The substrate solution was subsequently removed and the cells were washed three times with PBS. Flow cytometric analysis was used to determine the levels of ROS and CytExpert software (version 1.2; Beckman Coulter, Inc.) was used to analyze the data.

Statistical analysis. Statistical analyses were performed using SPSS software (version 21.0; IBM Corp.). Data are expressed as the mean \pm standard deviation. Multiple comparisons between groups were performed using one-way ANOVA followed by Tukey's post hoc test. All experiments were replicated three times. $\mathrm{P}<0.05$ was considered to indicate a statistically significant difference.

\section{Results}

Quinalizarin inhibits the viability of human breast cancer cells but not normal cells. In order to evaluate the cytotoxic effects of quinalizarin in human breast cancer cells, MCF-7, T47D and MDA-MB231 cells were treated with different concentrations of quinalizarin or 5-FU $(1,3,10,30$ and $100 \mu \mathrm{mol} / \mathrm{l})$ for $24 \mathrm{~h}$, after which the MTT assay was performed to measure cell viability. Quinalizarin inhibited MDA-MB231 (estrogen-receptor-negative, $\mathrm{IC}_{50}$ value $30.11 \mu \mathrm{mol} / \mathrm{l}$ ) cell viability and significantly inhibited the viability of the estrogen-receptor-positive cell lines in a dose-dependent manner, more so than 5-FU. The $\mathrm{IC}_{50}$ values for quinalizarin in MCF-7 and T47D cells were 12.66 and $15.21 \mu \mathrm{mol} / 1$, respectively (Fig. 1A). Due to the MCF-7 cells having the lowest $\mathrm{IC}_{50}$ value $(12.66 \mu \mathrm{mol} / \mathrm{l})$ and being the most sensitive to quinalizarin, this cell line was selected as the model system to investigate the effects of quinalizarin on apoptosis and cell cycle arrest. Furthermore, there were no effective cytotoxic effects of quinalizarin when compared with the 5-FU-treated group in the L-02, IMR-90 and 293-T cell lines (Fig. 1B). These results demonstrated that quinalizarin had cytotoxic effects in MCF-7, T47D and MDA-MB231 cell lines, but not in the L-02, IMR-90 and 293-T cell lines, which may provide initial evidence that the pro-apoptotic effects of quinazirilin are specific to estrogen-receptor-positive breast cancer cells.

Quinalizarin induces apoptosis in MCF-7 cells. To determine whether quinalizarin induces apoptosis in human breast cancer cells, MCF-7 cells were treated with $10 \mu \mathrm{mol} / 1$ quinalizarin or $10 \mu \mathrm{mol} / 1$ 5-FU for 3, 6, 12 and $24 \mathrm{~h}$, followed by Hoechst staining, flow cytometric analyses and western blotting to measure cell apoptosis. As presented in Fig. 2A, MCF-7 cells treated with quinalizarin for $24 \mathrm{~h}$ exhibited cell shrinkage and chromatin condensation, as demonstrated by a strong bright red fluorescence. The flow cytometric analysis results revealed that treatment with quinalizarin for $24 \mathrm{~h}$ markedly increased the rate of apoptosis to $29.61 \%$, and significantly increased cell apoptosis between 3 and $24 \mathrm{~h}$ compared with 5-FU (Fig. 2B). In addition, quinalizarin also significantly increased the expression levels of Bax, caspase-3 and PARP proteins in a time-dependent manner, and decreased the expression levels of Bcl-2 protein (Fig. 2C). These results suggested that quinalizarin-induced apoptosis was partially mediated by the mitochondrial pathway and caspase activation in MCF-7 cells.

Quinalizarin induces cell cycle arrest in MCF-7 cells. To investigate whether quinalizarin induced cell cycle arrest in human breast cancer cells, MCF-7 cells were treated with $10 \mu \mathrm{mol} / \mathrm{l}$ quinalizarin for $3,6,12$ and $24 \mathrm{~h}$, followed by flow cytometric analyses and western blotting to evaluate cell cycle arrest. Quinalizarin significantly increased the number of cells in the $\mathrm{G}_{2} / \mathrm{M}$ phase and decreased the number of cells in the $\mathrm{G}_{0} / \mathrm{G}_{1}$ and $\mathrm{S}$ phases in a time-dependent manner (Fig. 3A). The western blotting results revealed that the expression levels of 

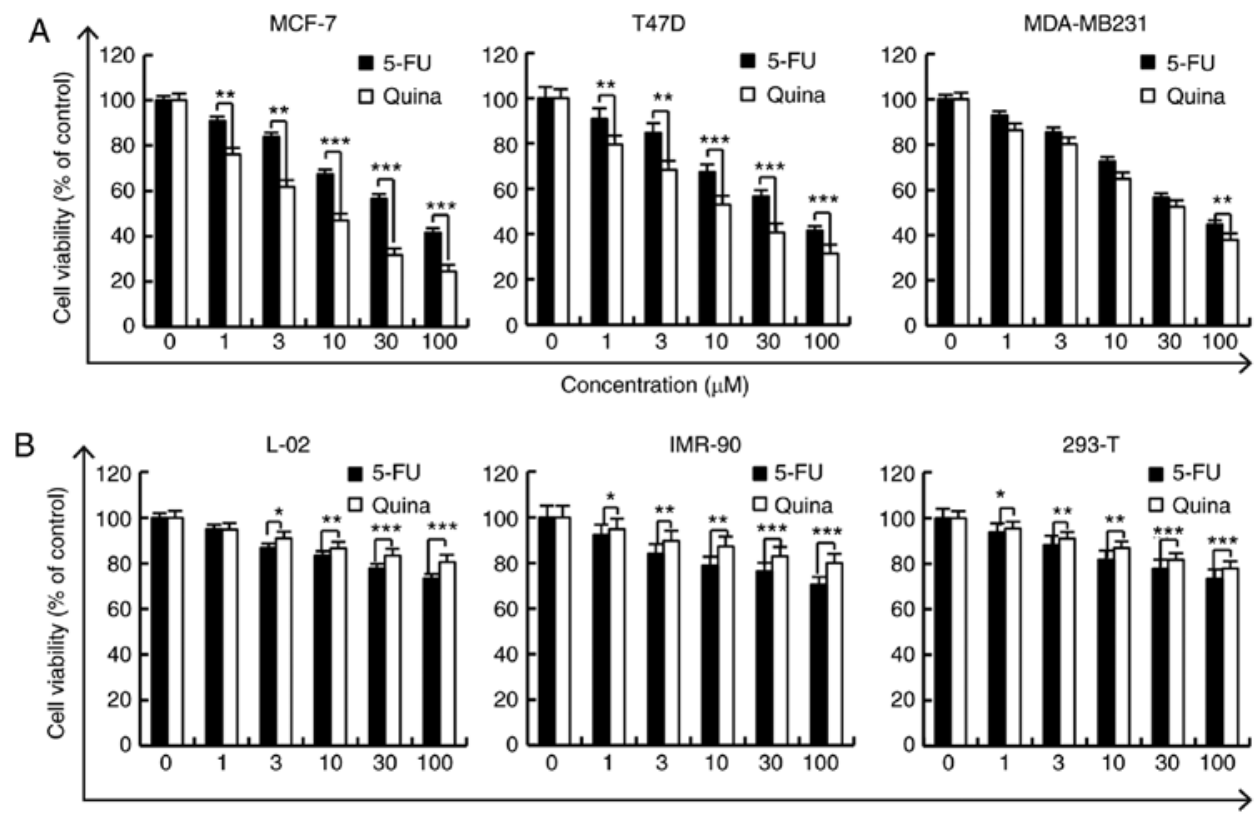

Concentration $(\mu \mathrm{M})$

Figure 1. Quinalizarin inhibits the viability of human breast cancer cells. (A) MCF-7, T47D and MDA-MB231 cells, and (B) L-02, IMR-90 and 293-T cells, were treated with $1,3,10,30$ and $100 \mu \mathrm{mol} / 15$-FU or quinalizarin for $24 \mathrm{~h}$, and then cell viability was measured via a MTT assay. The results are presented as the mean \pm standard deviation of three independent experiments. ${ }^{*} \mathrm{P}<0.05,{ }^{* *} \mathrm{P}<0.01$ and ${ }^{* * *} \mathrm{P}<0.001$, as indicated. 5-FU, 5-fluorouracil; Quina, quinalizarin.

A $5-\mathrm{FU}$
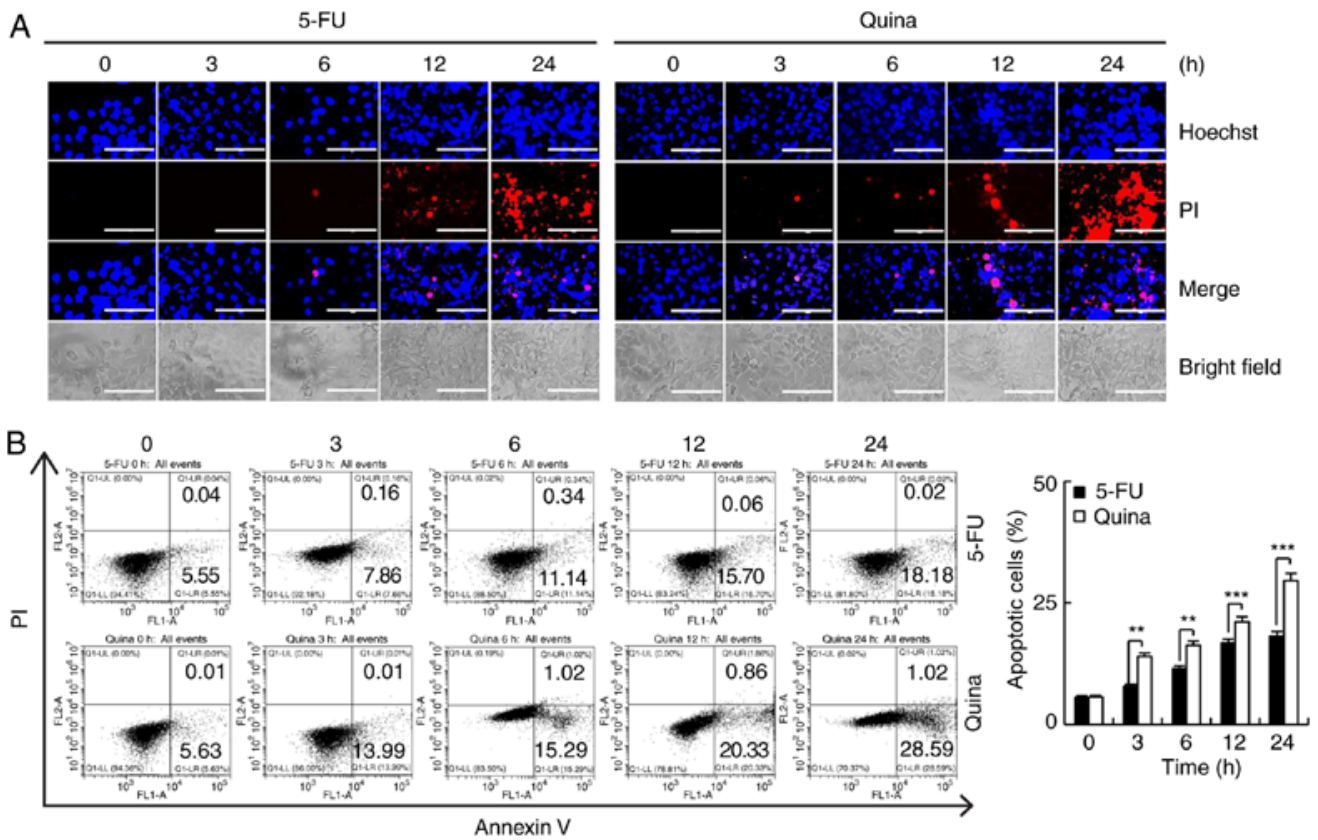

C
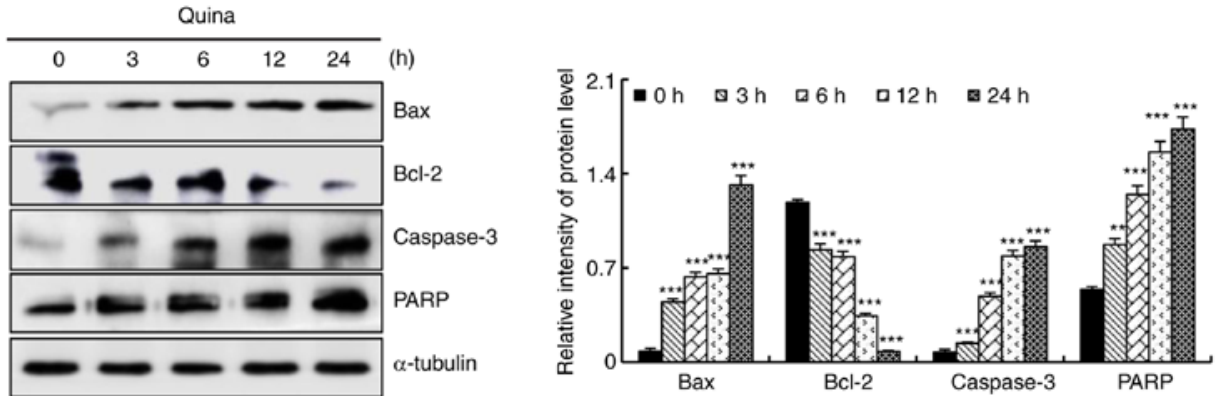

Figure 2. Quinalizarin induces apoptosis in human breast cancer cells. (A) Cells were treated with $10 \mu \mathrm{mol} / 1$ 5-FU or $10 \mu \mathrm{mol} / 1$ quinalizarin for 3, 6, 12 and $24 \mathrm{~h}$, after which the cell morphology and fluorescence intensity were observed by fluorescence microscopy. Scale bars, $200 \mu \mathrm{m}$. (B) Cells were treated with $10 \mu \mathrm{mol} / 1$ quinalizarin for 3, 6, 12 and $24 \mathrm{~h}$, and apoptosis was analyzed by flow cytometric analysis. ${ }^{* *} \mathrm{P}<0.01$ and ${ }^{* * * *} \mathrm{P}<0.001$, as indicated. (C) The expression levels of Bax, Bcl-2, caspase-3 and PARP in MCF-7 cells were analyzed via western blotting. Error bars indicate the mean \pm standard deviation of three independent experiments. ${ }^{* *} \mathrm{P}<0.01$ and ${ }^{* * * *} \mathrm{P}<0.001$ vs. 0 h. 5-FU, 5 -fluorouracil; Quina, quinalizarin; PI, propidium iodide; PARP, poly (ADP-ribose) polymerase. 
A

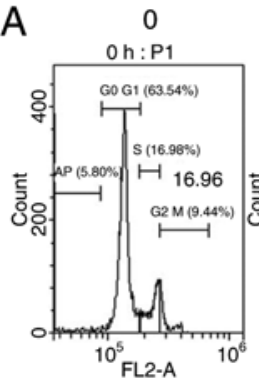

B
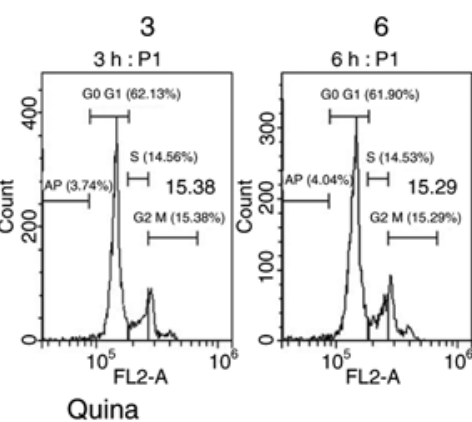

Quina
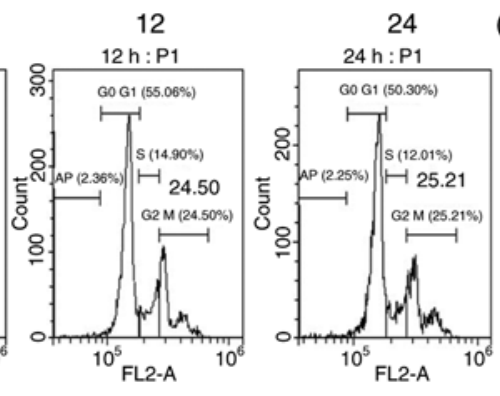

(h)

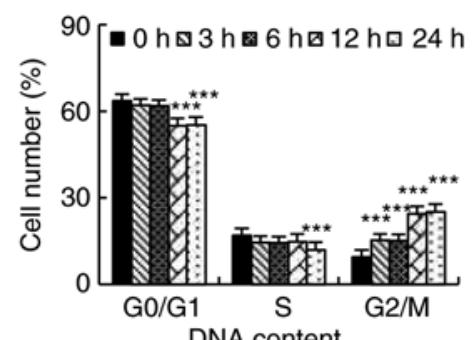

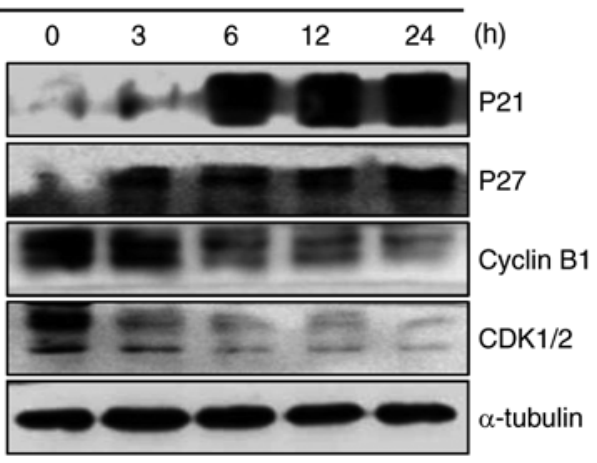

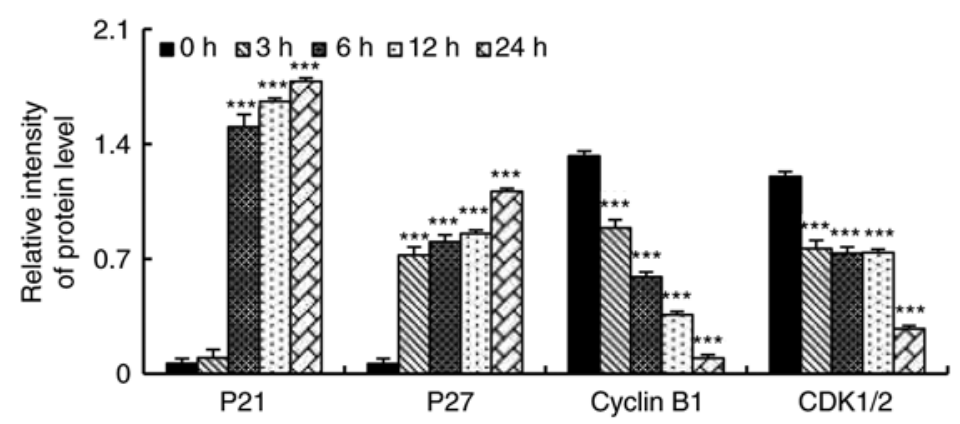

Figure 3. Quinalizarin induces $\mathrm{G}_{2} / \mathrm{M}$ phase arrest in human breast cancer cells. (A) Cells were treated with $10 \mu \mathrm{mol} / 1$ quinalizarin for 3, 6, 12 and $24 \mathrm{~h}$, and the cell cycle was analyzed via flow cytometric analysis. (B) The expression levels of CDK1/2, cyclin B1, p21 and p27 in MCF-7 cells were analyzed via western blotting. Error bars indicate the mean \pm standard deviation of three independent experiments. ${ }^{* * *} \mathrm{P}<0.001 \mathrm{vs} .0 \mathrm{~h}$. Quina, quinalizarin.

the $\mathrm{G}_{2} / \mathrm{M}$ phase-associated proteins $\mathrm{CDK} 1 / 2$ and cyclin $\mathrm{B} 1$ were decreased, and the expression levels of p21 and p27 were increased over time (Fig. 3B). These results suggested that quinalizarin caused $\mathrm{G}_{2} / \mathrm{M}$ phase cell cycle arrest through alterations in p21, p27 and $\mathrm{G}_{2} / \mathrm{M}$ phase cell cycle-associated protein expression in MCF-7 cells.

Quinalizarin induces apoptosis via MAPK, STAT3 and NF- $\kappa B$ signaling pathways in MCF-7 cells. In order to determine whether quinalizarin-induced MCF-7 cell apoptosis involved the MAPK, STAT3 and NF- $\kappa$ B signaling pathways, MCF-7 cells were treated with $10 \mu \mathrm{mol} / \mathrm{l}$ quinalizarin for $3,6,12$ and $24 \mathrm{~h}$, followed by western blotting to measure protein expression levels. Quinalizarin suppressed the level of p-ERK, p-STAT3 and NF- $\kappa B$ in a time-dependent manner, and increased the levels of p-JNK, p-p38 and i-kB (Fig. 4A). In order to investigate whether the MAPK signaling pathway is involved in the regulation of the STAT3 and NF- $\mathrm{KB}$ signaling pathways, MCF-7 cells were treated with the p38 inhibitor (SB203580), JNK inhibitor (SP600125) and ERK inhibitor (FR180204). After $24 \mathrm{~h}$, the decreased protein expression levels of p-STAT3 and NF- $\kappa$ B induced by quinalizarin were blocked by the addition of the p38 and JNK inhibitors. p-STAT3 and $\mathrm{NF}-\kappa \mathrm{B}$ protein expressions were further suppressed following the addition of the ERK inhibitor and quinalizarin, when compared with quinalizarin treatment alone (Fig. 4B). These results demonstrated that the MAPK signaling pathway can regulate the expression levels of STAT3 and NF- $\mathrm{KB}$, and quinalizarin induced MCF-7 cell apoptosis via the MAPK, STAT3 and NF- $\mathrm{kB}$ signaling pathways.

Quinalizarin induces apoptosis by accelerating ROS generation in MCF-7 cells. To determine whether quinalizarin-induced cell apoptosis was preceded by ROS generation, MCF-7 cells were treated with quinalizarin $(10 \mu \mathrm{mol} / \mathrm{l})$ for $24 \mathrm{~h}$, followed by flow cytometric analyses and western blotting to measure ROS levels. Quinalizarin increased the levels of intracellular ROS accumulation in MCF-7 cells in a time-dependent manner (Fig. 5A), but pre-incubation with NAC for $24 \mathrm{~h}$ partially prevented the quinalizarin-induced accumulation of ROS. Following pretreatment with NAC, the quinalizarin-induced apoptosis was reversed (Fig. 5B). NAC blocked the quinalizarin-induced decrease in the expression levels of p-ERK, p-STAT3 and $\mathrm{NF}-\mathrm{\kappa B}$, and also blocked the quinalizarin-induced increase in the expression levels of p-JNK, p-p38, i- $\kappa \mathrm{B}$, caspase-3 and PARP (Fig. 5C). These results demonstrated that ROS generation is a major regulator of quinalizarin-induced mitochondrial-dependent apoptosis and $\mathrm{G}_{2} / \mathrm{M}$ cell cycle arrest through ROS-mediated MAPK, STAT3 and NF- $\mathrm{kB}$ signaling pathways in MCF-7 cells (Fig. 6).

\section{Discussion}

Anthraquinone compounds, an important class of natural and synthetic compounds, include emodin, rhein, aloe-emodin, apigenin and quinalizarin (23). Numerous studies have reported that rhein, apigenin, aloe-emodin and emodin affect the cell proliferation, migration and apoptosis of different pathological and genetic types of human cancer cell lines $(24,25)$. In addition, studies have also reported that anthraquinone derivatives possess a number of identical activities as they have an identical mother nucleus $(26,27)$. Similarly, the present study demonstrated that quinalizarin, an anthraquinone compound, significantly inhibited MCF-7 ( IC $\left._{50}, 12.66 \mu \mathrm{mol} / \mathrm{l}\right)$ and T47D $\left(\mathrm{IC}_{50} 15.21 \mu \mathrm{mol} / \mathrm{l}\right)$ cell viability as determined by the MTT 
A

Quina
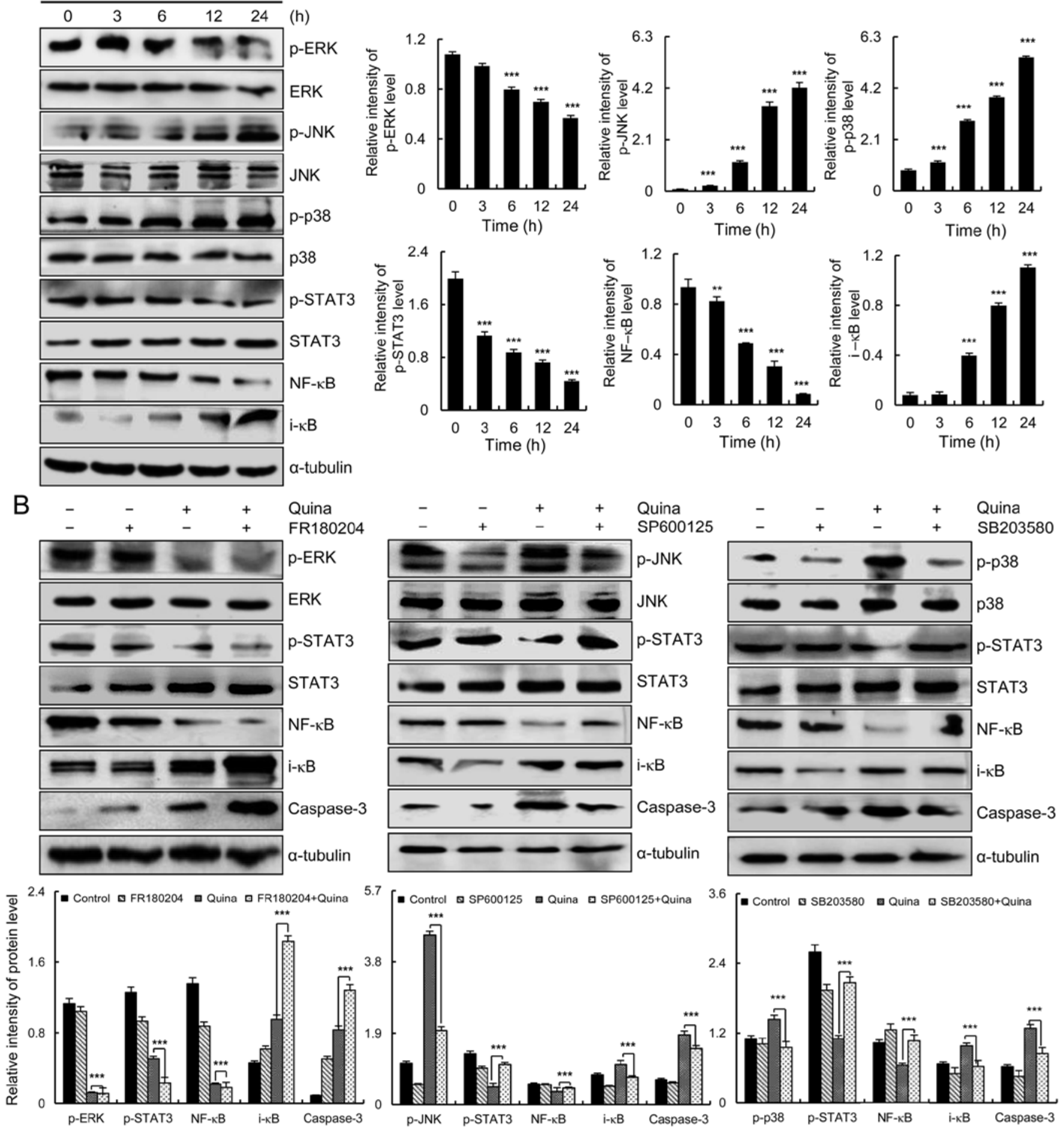

Figure 4. Quinalizarin induces cell apoptosis in human breast cancer cells via the MAPK, STAT3 and NF-kB signaling pathways. (A) Expression levels of

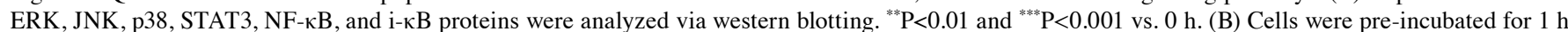

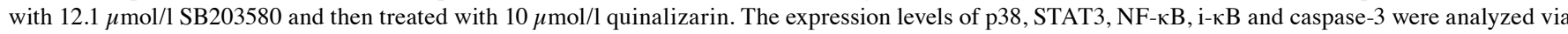
western blotting. The expression levels of $\mathrm{p}-\mathrm{JNK}, \mathrm{STAT} 3, \mathrm{NF}-\mathrm{kB}, \mathrm{i}-\mathrm{\kappa B}$ and caspase-3 were analyzed via western blotting. Cells were pre-incubated for $1 \mathrm{~h}$

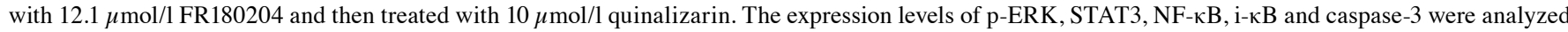
via western blotting. Error bars indicate the mean \pm standard deviation of three independent experiments. ${ }^{* * *} \mathrm{P}<0.001$, as indicated. MAPK, mitogen-activated protein kinase; STAT3, signal transducer and activator of transcription-3; ERK, extracellular signal-regulated kinase; JNK, c-Jun N-terminal kinase; p-, phosphorylated; quina, quinalizarin.

assay, and had less toxicity in L-02, IMR-90 and 293-T cells. Thus, quinalizarin may possess effective anti-tumor activities and decrease cytotoxicity in normal human cells compared with 5-FU. In order to confirm this theory, the present study investigated the anti-tumor mechanisms of quinalizarin in human breast cancer cell lines.

Apoptosis, a form of programmed cell death, is a critical defense mechanism in inhibiting the development 

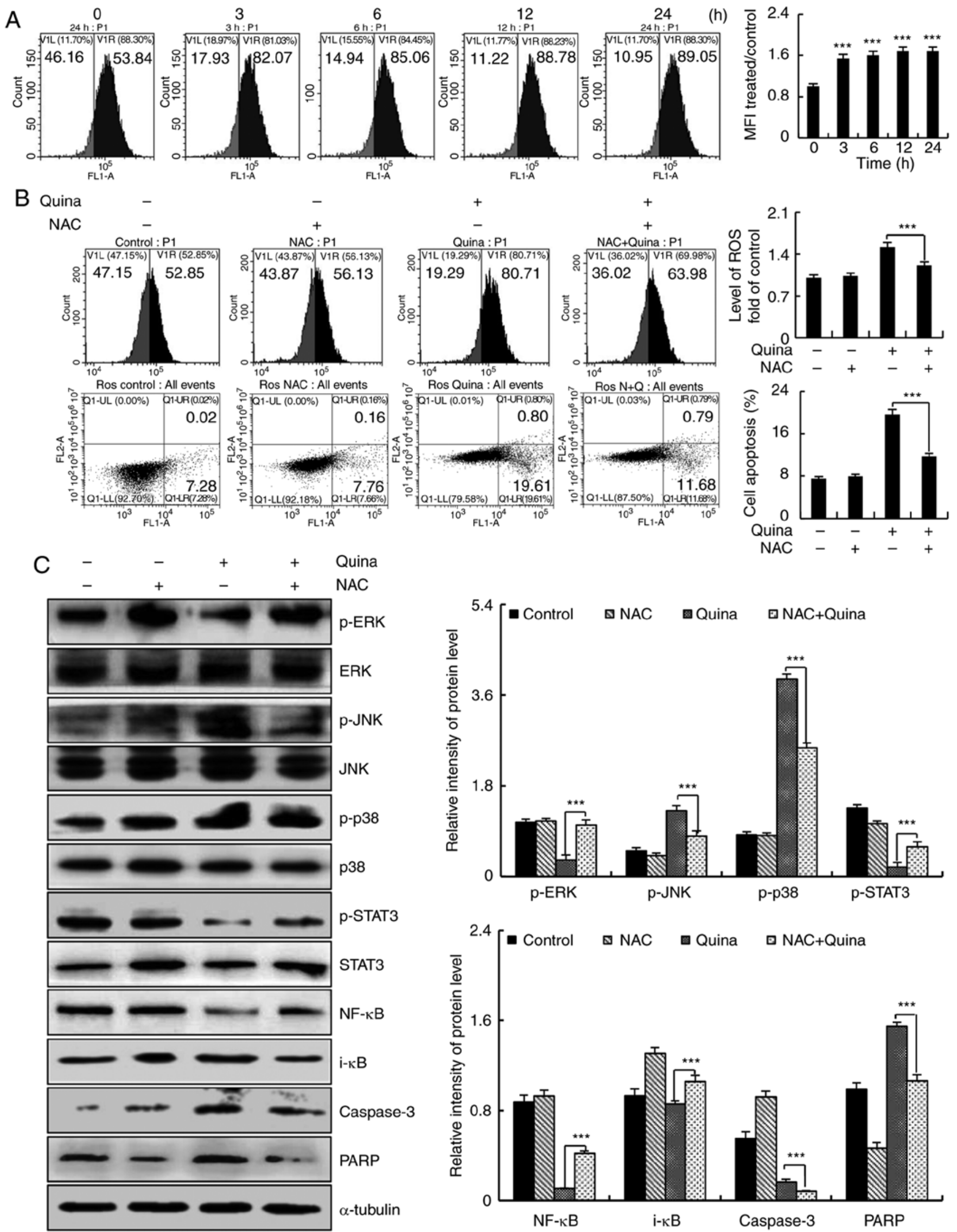
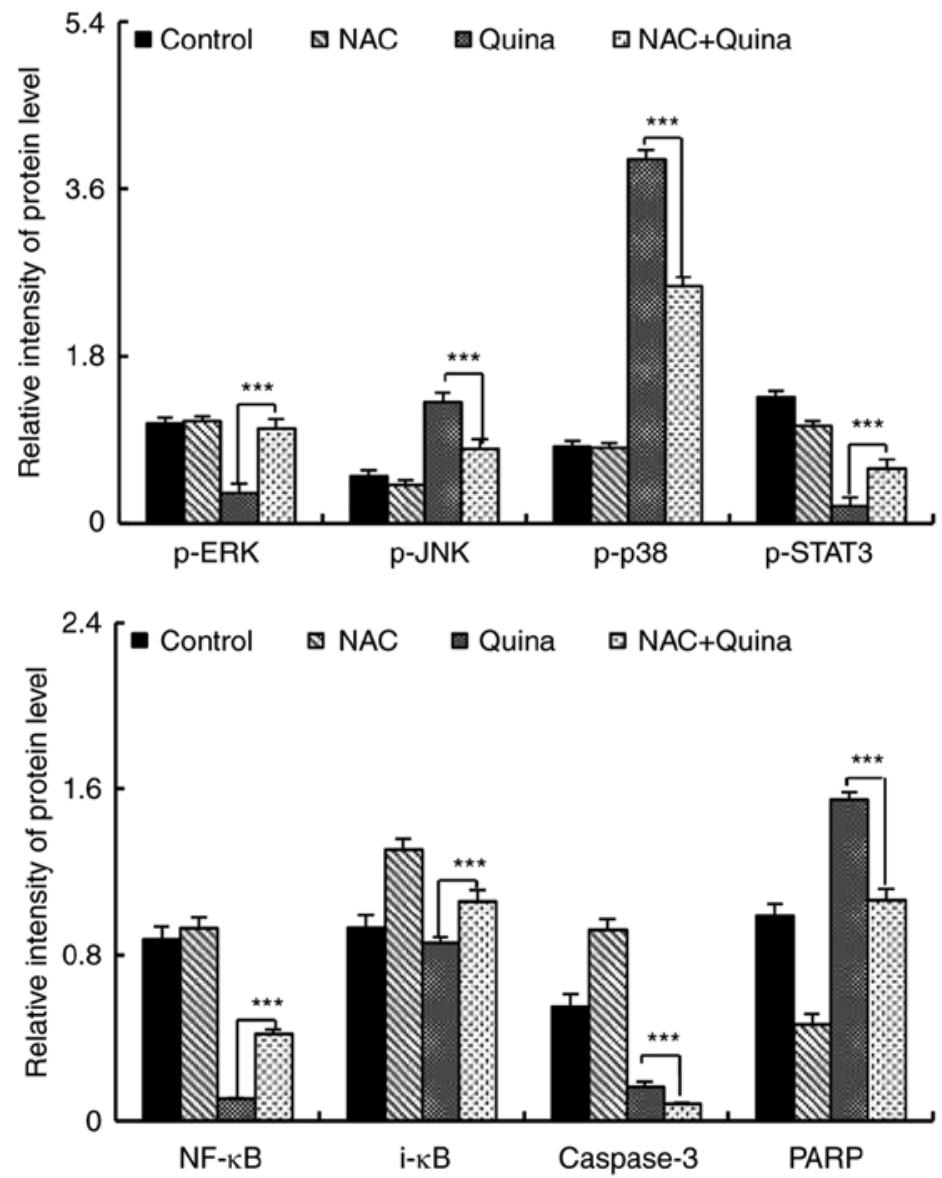

Figure 5. Quinalizarin induces ROS-mediated apoptosis in human breast cancer cells. (A) Cells were treated with $10 \mu$ mol/1 quinalizarin for 3, 6, 12 and $24 \mathrm{~h}$, and the intracellular ROS levels were analyzed via flow cytometric analyses. ${ }^{* * *} \mathrm{P}<0.001 \mathrm{vs} .0 \mathrm{~h}$. (B) Cells were treated with NAC or quinalizarin for $24 \mathrm{~h}$, the generation of ROS and cell apoptosis were analyzed via flow cytometric analyses. ${ }^{* * *} \mathrm{P}<0.001$, as indicated. (C) The expression levels of ERK, JNK, p38, STAT3, NF- $\mathrm{B}$, i- $\mathrm{\kappa B}$, caspase-3 and PARP were analyzed via western blotting. Error bars indicate the mean \pm standard deviation of three independent experiments. ${ }^{* * *} \mathrm{P}<0.001$, as indicated. ROS, reactive oxygen species; NAC, N-acetyl-L-cysteine; ERK, ERK, extracellular signal-regulated kinase; JNK, c-Jun $\mathrm{N}$-terminal kinase; STAT3, signal transducer and activator of transcription-3; p-, phosphorylated; PARP, poly (ADP-ribose) polymerase. 


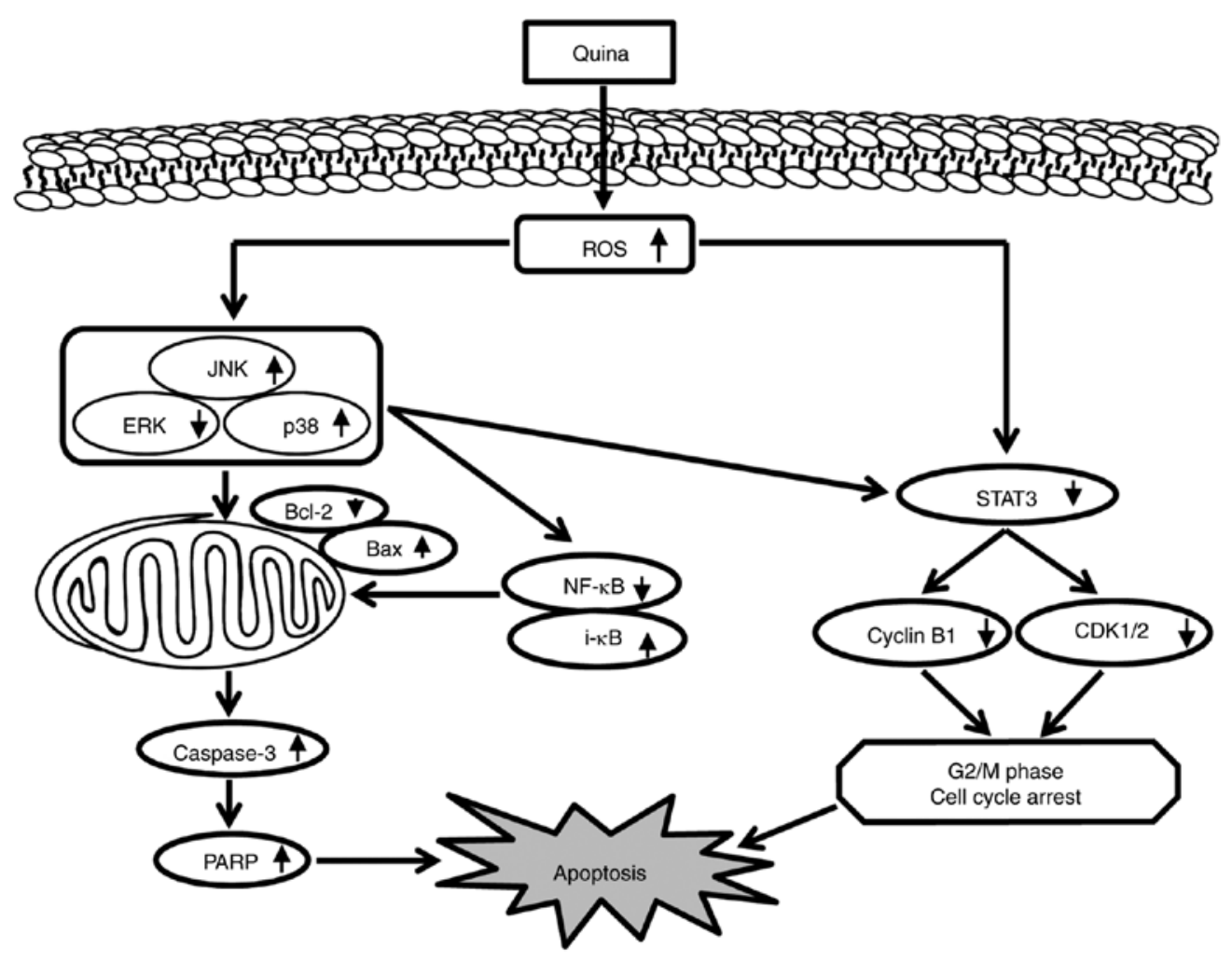

Figure 6. Schematic diagram of the signaling pathways in MCF-7 cells affected by quinalizarin. Quinalizarin induced apoptosis in the human breast cancer cells. The anticancer effects of quinalizarin induced ROS-mediated mitochondrial apoptosis by the MAPK, STAT3, and NF-kB signaling pathways. ROS, reactive oxygen species; MAPK, mitogen-activated protein kinase; STAT3, signal transducer and activator of transcription-3; quina, quinalizarin; JNK, c-Jun N-terminal kinase; ERK, ERK, extracellular signal-regulated kinase; PARP, poly (ADP-ribose) polymerase.

of cancer (28). The mitochondrial pathway is one form of apoptosis signaling pathway. Bax and Bcl-2 are Bcl-2 family members that are fundamental for the balance between cell survival and death in the mitochondrial pathway (29). In the mitochondrial pathway, caspase- 3 is primarily responsible for PARP activation during cell apoptosis (30). A recent study demonstrated that emodin, an anthraquinone, decreased the expression levels of Bcl-2; increased the levels of caspase-3, PARP and Bax; and induced apoptosis by modulating the expression of apoptosis-associated genes in human breast cancer cells (31). Similarly, the results from the present study revealed that quinalizarin significantly induced the apoptosis of MCF-7 cells by promoting the expression levels of Bax, downregulating Bcl-2 and activating caspase- 3 and PARP. These findings suggested that quinalizarin induced apoptosis via the mitochondrial pathway in the human breast cancer cell line, MCF-7.

In addition to the activation of the mitochondrial pathway checkpoint, cell cycle control is another primary regulatory mechanism that controls cell growth and induces cell apoptosis (32). In eukaryotic cells, CDK1/2 and cyclin B1 proteins control entry into mitosis $\left(\mathrm{G}_{2} / \mathrm{M}\right)$ and are involved in regulatory and structural processes required for mitosis, such as formation of the spindle and attachment of chromosomes to the spindle. However, these CDK/cyclin complexes are negatively regulated by $\mathrm{p} 21$ and $\mathrm{p} 27$. Thus, tumor-associated $\mathrm{G}_{2} / \mathrm{M}$ phase arrest is often mediated by alterations in cyclin B1/CDK complex protein activity and the expression levels of p21 and p27 (33-36). Furthermore, previous studies have demonstrated that the MAPK and STAT3 signaling pathways regulate the eukaryotic cell cycle (37-38). Aloe-emodin, a type of anthraquinone, induces cell death through S-phase arrest and caspase-dependent pathways in human tongue squamous cancer SCC-4 cells, which involves ROS generation (39). The results from the present study coincide with evidence suggesting that quinalizarin causes $\mathrm{G}_{2} / \mathrm{M}$ phase arrest, as the expression levels of p21 and p27 were significantly increased, and the cyclin $\mathrm{B} 1$ and $\mathrm{CDK} 1 / 2$ complex protein, which is required for progression through the $G_{2}$ and $M$ phases, were inhibited. These results suggested that quinalizarin-mediated inhibition of MCF-7 cell proliferation may involve $\mathrm{G}_{2} / \mathrm{M}$ phase arrest and expression of $\mathrm{G}_{2} / \mathrm{M}$ phase-associated proteins.

The present study also focused on numerous crucial protein kinases that play roles in regulating the cell cycle and apoptosis, including JNK, p38, ERK, STAT3 and NF-кB. JNK and p38 induce apoptosis, while ERK promotes cell survival (40-42). Rhein, a type of anthraquinone, induced apoptosis in human and rat glioma cells by blocking ERK kinase activity (43). The activation of and interactions between STAT3 and NF- $\mathrm{KB}$ have been demonstrated in a number of different types of cancer, such as colon, gastric and liver cancer (44). Apigenin, another type of anthraquinone, induces apoptosis by decreasing the expression levels of p-STAT3 and blocking the activation of the STAT3 and NF- $\kappa B$ signaling pathway in MCF-7 cells (45). The results from the present study demonstrated that quinalizarin could upregulate the expression levels of p-p38, p-JNK and $\mathrm{i}-\kappa \mathrm{B}$, and inhibit $\mathrm{p}$-ERK, $\mathrm{p}$-STAT3 and NF- $\mathrm{B}$ activity. The association between the MAPK, STAT3 and NF- $\mathrm{KB}$ signaling 
pathways were also investigated by inhibiting p-JNK, p-p38 and $\mathrm{p}$-ERK activation. It was important to note that the protein levels of p-STAT3 and NF- $\mathrm{NB}$ increased, and caspase-3 and $\mathrm{i}-\kappa \mathrm{B}$ decreased following treatment with $\mathrm{JNK}$ or $\mathrm{p} 38$ inhibitors. Inhibition of ERK activation further decreased the protein levels of $\mathrm{p}-\mathrm{STAT} 3$ and $\mathrm{NF}-\kappa \mathrm{B}$, and caspase -3 and $\mathrm{i}-\kappa \mathrm{B}$ levels increased in MCF-7 cells. These data demonstrate that p-STAT3 and NF- $\kappa \mathrm{B}$ were decreased in quinalizarin-treated cells and were regulated by MAPK signaling. Therefore, MAPK is considered to be an important factor for the quinalizarin-mediated induction of apoptosis in MCF-7 cells. These results also demonstrated that quinalizarin-induced apoptosis was mediated through the MAPK, STAT3 and NF- $\kappa$ B signaling pathways. In addition, it has been reported that copper chelating peptide-anthraquinones have the redox effects of a quinone ring to generate free radical species capable of damaging DNA (46). Quinone-containing drugs undergo a one-electron reduction to the corresponding semiquinone radicals which, in the presence of molecular oxygen, produces a superoxide anion radical, hydrogen peroxide (47). The quinone ring structures of copper chelating peptide-anthraquinones are similar to that of quinalizarin $(46,48)$. Thus, it was hypothesized that quinalizarin caused cell oxidative stress, and induced MCF-7 cell apoptosis by regulating the MAPK, STAT3 and NF- $\mathrm{B}$ signaling pathways.

ROS, which serve as redox messengers, are usually maintained at tolerable levels under normal physiological conditions, but high ROS levels elicit oxidative stress, leading to cell death via apoptosis (49-52). The overproduction of intracellular ROS has been associated with the apoptotic response induced by several anticancer agents (53), and excessive ROS accumulation promotes cell apoptosis through various mechanisms, including prolonged MAPK activation and inhibition of p-STAT3 and NF- $\mathrm{B}(54,55)$. A recent study revealed emodin-induced apoptosis of colon cancer cells in a ROS-dependent manner (56). It has been reported that emodin-mediated ROS production acts as an early and upstream change in the cell death cascade to antagonize cytoprotective ERK and AKT signaling, Bcl-2 and Bax modulation, and caspase activation, consequently leading to apoptosis in A549 cells (57). The results from the present study coincide with the aforementioned studies. DCFH-DA staining, one of the most straightforward techniques for directly measuring the redox state of cells (58), demonstrated that quinalizarin-induced apoptosis was accompanied by ROS accumulation. In order to determine the association between quinalizarin-induced apoptosis and ROS, the NAC antioxidant was used to pretreat MCF-7 cells in the present study. The results revealed that quinalizarin did not directly regulate the MAPK, STAT3 and NF- $\mathrm{B}$ signaling pathways, but rather induced their indirect regulation by stimulating ROS accumulation, thereby promoting apoptosis in MCF-7 cells.

In conclusion, the present study demonstrated that quinalizarin induced ROS generation and subsequently inhibited the activation of the MAPK,STAT3 and NF- $\kappa$ B signaling pathways, which increased $\mathrm{G}_{2} / \mathrm{M}$ cell cycle arrest and caspase-dependent apoptosis in human breast cancer cells. These data are indicative of the value of further studies regarding the application of quinalizarin as a potential treatment for breast cancer.

\section{Acknowledgements}

Not applicable.

\section{Funding}

The present study was funded by the Multigrain Production and Processing Characteristic Discipline Construction Project (grant no. 2042070010), the Postdoctoral Scientific Research Foundation of Heilongjiang Province of China (grant no. LBH-Q13132) and the Heilongjiang Bayi Agricultural University Support Program for 'San Zong' (grant no. TDJH201805).

\section{Availability of data and materials}

The datasets used or analyzed during the present study are available from the corresponding author upon reasonable request.

\section{Authors' contributions}

CHJ and CQY conceived and designed the study. YaQZ, YYF, YHL, YuQZ, XYJ, YCF, YNS and JRW performed the experiments. YaQZ, YYF and YHL analyzed the data. YaQZ and YYF wrote the manuscript. All authors read and approved the final manuscript.

\section{Ethics approval and consent to participate}

Not applicable.

\section{Patient consent for publication}

Not applicable.

\section{Competing interests}

The authors declare that they have no competing interests.

\section{References}

1. Elzawawy A: Breast cancer systemic therapy: The need for more economically sustainable scientific strategies in the world. Breast Care (Base) 3: 434-438, 2008.

2. Bray F, Mccarron P and Parkin DM: The changing global patterns of female breast cancer incidence and mortality. Breast Cancer Res 6: 229-239, 2004

3. Van Agthoven T, Sieuwerts AM, Meijer D, Meijer-van Gelder ME, van Agthoven TL, Sarwari R, Sleijfer S, Foekens JA and Dorssers LC: Selective recruitment of breast cancer anti-estrogen resistance genes and relevance for breast cancer progression and tamoxifen therapy response. Endocr Relat Cancer 17: 215-230, 2010.

4. Feiten S, Dünnebacke J, Heymanns J, Köppler H, Thomalla J, Van Roye C, Wey D and Weide R: Breast cancer morbidity: Questionnaire survey of patients on the long term effects of disease and adjuvant therapy. Dtsch Arztebl Int 111: 537-544, 2014.

5. Van Cutsem E, Moiseyenko VM, Tjulandin S, Majlis A, Constenla M, Boni C, Rodrigues A, Fodor M, Chao Y, Voznyi E, et al: Phase III study of docetaxel and cisplatin plus fluorouracil compared with cisplatin and fluorouracil as first-line therapy for advanced gastric cancer: A report of the V325 study group. J Clin Oncol 24: 4991-4997, 2006.

6. Fesik SW: Promoting apoptosis as a strategy for cancer drug discovery. Nat Rev Cancer 5: 876-885, 2005. 
7. Yu I and Cheung WY: Comparison of 5-FU versus capecitabine in combination with mitomycin or cisplatin in the treatment of anal cancer. J Clin Oncol 35: 680-680, 2017.

8. Haagenson KK and Wu GS: Mitogen activated protein kinase phosphatases and cancer. Cancer Biol Ther 9: 337-340, 2010.

9. Shao Y and Aplin AE: ERK2 phosphorylation of serine 77 regulates Bmf pro-apoptotic activity. Cell Death Dis 3: e253, 2012.

10. Inoue J, Gohda J, Akiyama T and Semba K: NF-kappaB activation in development and progression of cancer. Cancer Sci 98 268-274, 2007.

11. Tang X, Soch E, Shishodia S, Diane LJ, Jack L, Waun KH, Bharat A and Ignacio IW: Immunohistochemical analysis indicates that nuclear factor- $\kappa \mathrm{B}$ (NF-alysis frequently activated in lung cancer. Cancer Res 46: 1-5, 2005.

12. Grivennikov SI and Karin M: Dangerous liaisons: STAT3 and NF-kappaB collaboration and crosstalk in cancer. Cytokine Growth Factor Rev 21: 11-19, 2010.

13. Zhang J, Wang X, Vikash V, Ye Q, Wu D, Liu Y and Dong W: ROS and ROS-mediated cellular signaling. Oxid Med Cell Longev 2016: 4350965, 2016.

14. Jacquemin G, Margiotta D, Kasahara A, Bassoy EY, Walch M Thiery J, Lieberman J and Martinvalet D: Granzyme B-induced mitochondrial ROS are required for apoptosis. Cell Death Differ 22: 862-874, 2015.

15. Redzadutordoir M and Averillbates DA: Activation of apoptosis signalling pathways by reactive oxygen species. Biochim Biophys Acta 1863: 2977-2992, 2016.

16. Wen L, Lu X, Wang R, Jin X, Hu L and You C: Pyrroloquinoline quinone induces chondrosarcoma cell apoptosis by increasing intracellular reactive oxygen species. Mol Med Rep 17: 7184-7190, 2018

17. Bu HQ, Cai K, Shen F, Bao XD, Xu Y, Yu F, Pan HQ, Chen CH Du ZJ and Cui JH: Induction of apoptosis by capsaicin in hepatocellular cancer cell line SMMC-7721 is mediated through ROS generation and activation of JNK and p38 MAPK pathways. Neoplasma 62: 582-591, 2015.

18. Vogel J, Bumgarner J, Espinosa N and Young W: An evaluation of the use of resistivity counters in the touchet river in washington and the imnaha river in oregon. Am Fish Soc 33: 6953-6960, 2011

19. Piska K, Koczurkiewicz P, Bucki A, Wójcik-Pszczoła K, Kołaczkowski M and Pekala E: Metabolic carbonyl reduction of anthracyclines-role in cardiotoxicity and cancer resistance. Reducing enzymes as putative targets for novel cardioprotective and chemosensitizing agents. Invest New Drugs 35: 375-385, 2017

20. Cozza G, Venerando A, Sarno S and Pinna LA: The selectivity of CK2 inhibitor quinalizarin: A reevaluation. Biomed Res Int 2015: 1-9, 2015.

21. Meng LQ, Liu C, Luo YH, Piao XJ, Wang Y, Zhang Y, Wang JR, Wang $\mathrm{H}$, Xu WT, Liu Y, et al: Quinalizarin exerts an anti-tumour effect on lung cancer A549 cells by modulating the Akt, MAPK, STAT3 and p53 signaling pathways. Mol Med Rep 17: 2626-2634, 2018.

22. Zhou Y, Li K, Zhang S, Li Q, Li Z, Zhou F, Dong X, Liu L, Wu G and Meng R: Quinalizarin, a specific CK2 inhibitor, reduces cell viability and suppresses migration and accelerates apoptosis in different human lung cancer cell lines. Indian J Cancer 52 (Suppl 2): e119-e124, 2015.

23. Malik EM and Müller CE: Anthraquinones as pharmacological tools and drugs. Med Res Rev 36: 705-748, 2016.

24. Lordan S, O'Neill C and O'Brien NM: Effects of apigenin, lycopene and astaxanthin on 7 beta-hydroxycholesterol-induced apoptosis and Akt phosphorylation in U937 cells. Br J Nutr 100 287-296, 2008.

25. Chen YY, Chiang SY, Lin JG, Ma YS, Liao CL, Weng SW, Lai TY and Chung JG: Emodin, aloe-emodin and rhein inhibit migration and invasion in human tongue cancer SCC-4 cells through the inhibition of gene expression of matrix metalloproteinase-9. Int J Oncol 36: 1113-1120, 2010.

26. Zhang YY, Li ZC, Zhu JK, Yang ZY, Wang QJ, He PG and Hang YZ, Pin JW, Yu GH and Fang Z: Simultaneous determination of flavonoids and anthraquinones in chrysanthemum by capillary electrophoresis with amperometry detection. Chin Chem Lett 21: 1231-1234, 2010.

27. Zong JR, Chao ZM, Liu ZL and Wang J: Review about structure-function relationships of anthraquinone derivatives from Radix et Rhizoma Rhei. Zhongguo Zhong Yao Za Zhi 33 : 2424-2427, 2008 (In Chinese).

28. Martin KR: Using nutrigenomics to evaluate apoptosis as a preemptive target in cancer prevention. Curr Cancer Drug Targets 7: 438-446, 2007
29. Zheng JH, Viacava Follis A, Kriwacki RW and Moldoveanu T: Discoveries and controversies in BCL-2 proteins-mediated apoptosis. FEBS J 283: 2690-2700, 2016.

30. Alenzi FQ, Lotfy M and Wyse R: Swords of cell death: Caspase activation and regulation. Asian Pac J Cancer Prev 11: 271-280, 2010.

31. Zu C, Zhang M, Xue H, Cai X, Zhao L, He A, Qin G, Yang C and Zheng X: Emodin induces apoptosis of human breast cancer cells by modulating the expression of apoptosis-related genes. Oncol Lett 10: 2919-2924, 2015 .

32. Antonsson A and Persson JL: Induction of apoptosis by staurosporine involves the inhibition of expression of the major cell cycle proteins at the $\mathrm{G}(2) / \mathrm{m}$ checkpoint accompanied by alterations in Erk and Akt kinase activities. Anticancer Res 29: 2893-2898, 2009

33. Gao SY, Li J, Qu XY, Zhu N and Ji YB: Downregulation of Cdk1 and cyclinB1 expression contributes to oridonin-induced cell cycle arrest at G2/M phase and growth inhibition in SGC-7901 gastric cancer cells. Asian Pac J Cancer Prev 15: 6437-6441, 2014.

34. Nasheuer HP, Smith R, Bauerschmidt C, Grosse F and Weisshart K: Initiation of eukaryotic DNA replication: Regulation and mechanisms. Prog Nucleic Acid Res Mol Biol 72: 41-70, 2002

35. Santamaria D and Ortega S: Cyclins and CDKS in development and cancer: Lessons from genetically modified mice. Front Biosci 11: 1164-1188, 2006.

36. Zhang Z, Leonard SS, Huang C, Castranova V and Shi X: Role of reactive oxygen species and MAPKs in vanadate-induced G(2)/M phase arrest. Free Radic Biol Med 34: 1333-1342, 2003.

37. Wang XH, Liu BR, Qu B, Xing H, Gao SL, Yin JM, Wang XF and Cheng YQ: Silencing STAT3 may inhibit cell growth through regulating signaling pathway, telomerase, cell cycle, apoptosis and angiogenesis in hepatocellular carcinoma: Potential uses for gene therapy. Neoplasma 58: 158-171, 2011

38. Clotet J, Vendrell J and Escoté X: Control of the cell cycle progression by the MAPK Hog1. MAP Kinase 2: e3, 2013.

39. Chiu TH, Lai WW, Hsia TC, Yang JS, Lai TY, Wu PP, Ma CY, Yeh CC, Ho CC, Lu HF, et al: Aloe-emodin induces cell death through S-phase arrest and caspase-dependent pathways in human tongue squamous cancer SCC- 4 cells. Anticancer Res 29: 4503-4511, 2009.

40. Su Y, Li G, Zhang X, Gu J, Zhang C, Tian Z and Zhang J: JSI-124 inhibits glioblastoma multiforme cell proliferation through $\mathrm{G}(2) / \mathrm{M}$ cell cycle arrest and apoptosis augment. Cancer Biol Ther 7: 1243-1249, 2008.

41. Guo Y, Lin D, Zhang M, Zhang X, Li Y, Yang R, Lu Y, Jin X, Yang M, Wang M, et al: CLDN6-induced apoptosis via regulating ASK1-p38/JNK signaling in breast cancer MCF-7 cells. Int J Oncol 48: 2435-2444, 2016.

42. Cook SJ, Stuart K, Gilley R and Sale MJ: Control of cell death and mitochondrial fission by ERK1/2 MAP Kinase signaling. FEBS J 284: 4177-4195, 2017.

43. Tang N, Chang J, Lu HC, Zhuang Z, Cheng HL, Shi JX and Rao J: Rhein induces apoptosis and autophagy in human and rat glioma cells and mediates cell differentiation by ERK inhibition. Microb Pathog 113: 168-175, 2017.

44. Degoricija M, Situm M, Korać J, Miljković A, Matić K, Paradžik M, Marinović Terzić I, Jerončić A, Tomić S and Terzić J: High NF- $\kappa$ B and STAT3 activity in human urothelial carcinoma: A pilot study. World J Urol 32: 1469-1475, 2014.

45. Seo HS, Choi HS, Kim SR, Choi YK, Woo SM, Shin I, Woo JK, Park SY, Shin YC and Ko SG: Apigenin induces apoptosis via extrinsic pathway, inducing p53 and inhibiting STAT3 and NFкB signaling in HER2-overexpressing breast cancer cells. Mol Cell Biochem 366: 319-334, 2012

46. Morier-Teissier E: Effect of a copper-chelating peptide on the anticancer activity of anthraquinones. J Pharm Belg 45: 347-354, 1990 (In French)

47. Morier-Teissier E, Bernier JL, Lohez M, Catteau JP and Hénichart JP: Free radical production and DNA cleavage by copper chelating peptide-anthraquinones. Anticancer Drug Des 5: 291-305, 1990.

48. Cozza G, Mazzorana M,Papinutto E, Bain J,Elliott M, di Maira G, Gianoncelli A, Pagano MA, Sarno S, Ruzzene M, et al: Quinalizarin as a potent, selective and cell-permeable inhibitor of protein kinase CK2. Biochem J 421: 387-395, 2009.

49. Prosperini A, Juan-García A, Font $G$ and Ruiz MJ: Beauvericin-induced cytotoxicity via, ROS production and mitochondrial damage in Caco-2 cells. Toxicol Lett 222: 204-211, 2013. 
50. Conway GE, Casey A, Milosavljevic V, Liu Y, Howe O, Cullen PJ and Curtin JF: Non-thermal atmospheric plasma induces ROS-independent cell death in U373MG glioma cells and augments the cytotoxicity of temozolomide. Br J Cancer 114: 435-443, 2016.

51. Wang $\mathrm{CH}, \mathrm{Wu} \mathrm{SB}, \mathrm{Wu} \mathrm{YT}$ and Wei $\mathrm{YH}$ : Oxidative stress response elicited by mitochondrial dysfunction: Implication in the pathophysiology of aging. Exp Biol Med (Maywood) 238: 450-460, 2013

52. Loor G, Kondapalli J, Schriewer JM, Chandel NS, Vanden Hoek TL and Schumacker PT: Menadione triggers cell death through ROS-dependent mechanisms involving PARP activation without requiring apoptosis. Free Radic Biol Med 49: 1925-1936, 2010.

53. Lo YLand Wang W: Formononetin potentiates epirubicin-induced apoptosis via ROS production in HeLa cells in vitro. Chem Biol Interact 205: 188-197, 2013.

54. Kim KY, Park KI, Kim SH, Yu SN, Lee D, Kim YW, Noh KT, Ma JY, Seo YK and Ahn SC: Salinomycin induces reactive oxygen species and apoptosis in aggressive breast cancer cells as mediated with regulation of autophagy. Anticancer Res 37: $1747-1758,2017$.
55. He $\mathrm{G}$ and Karin M: NF- $\mathrm{BB}$ and STAT3-key players in liver inflammation and cancer. Cell Res 21: 159-168, 2011.

56. Wang Y, Luo Q, He X, Wei H, Wang T, Shao J and Jiang X: Emodin induces apoptosis of colon cancer cells via induction of autophagy in a ROS-Dependent manner. Oncol Res 26: 889-899, 2018.

57. Su YT, Chang HL, Shyue SK and Hsu SL: Emodin induces apoptosis in human lung adenocarcinoma cells through a reactive oxygen species-dependent mitochondrial signaling pathway. Biochem Pharmacol 70: 229-241, 2005.

58. Eruslanov E and Kusmartsev S: Identification of ROS using oxidized DCFDA and flow-cytometry. Methods Mol Biol 594: $57-72,2010$

This work is licensed under a Creative Commons Attribution-NonCommercial-NoDerivatives 4.0 International (CC BY-NC-ND 4.0) License. 